
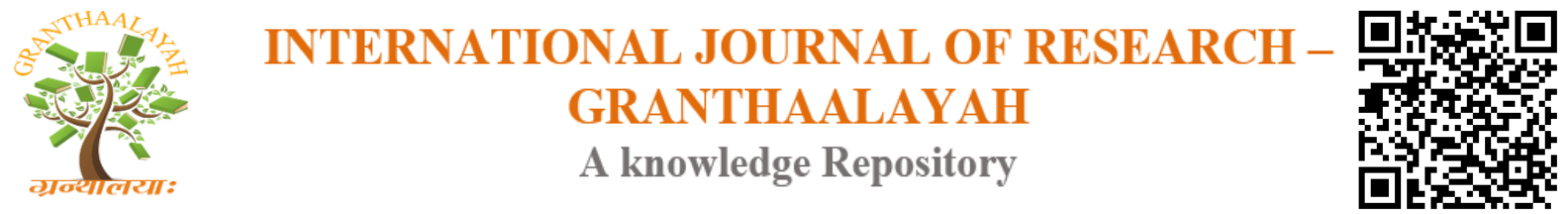

Management

\title{
DETERMINANTS OF RETAINED EARNINGS IN PROFITABLE STEEL COMPANIES IN INDIA: A STUDY OF STEEL SECTOR
}

\author{
Dr. Sohaib Masood ${ }^{* 1}$ \\ *1 Assistant Professor - Secretarial Practice Section, University Women’s Polytechnic, Aligarh \\ Muslim University, Aligarh, India
}

\begin{abstract}
In this paper an attempt has been made to identify the important determinants of retained earnings in profitable steel companies in steel sector of India and which have impact on the retention of earnings of steel companies under study. Multiple linear regression is used to identify the determinants of retained earnings for a period of sixteen years. Also the importance of retained earnings as a source of finance for steel sector companies is also studied in the paper.

Keywords: Retained Earnings; Multiple Linear Regression; PAT; DP; RES; CR; DER; INVS; INV; DEP; CF; CT.

Cite This Article: Dr. Sohaib Masood. (2018). "DETERMINANTS OF RETAINED EARNINGS IN PROFITABLE STEEL COMPANIES IN INDIA: A STUDY OF STEEL SECTOR." International Journal of Research - Granthaalayah, 6(1), 389-399. https://doi.org/10.29121/granthaalayah.v6.i1.2018.1633.
\end{abstract}

\section{Introduction}

Retained earnings refer to that part of corporate's net profit after tax which is not distributed to the shareholders as dividend but is reinvested in the business. Retained earnings therefore, are the sum of a company's profits after dividend payments, since the company's inception. They are also called earned surplus, retained capital or accumulated earnings. Retained earnings are an important source of internal or self-financing by a company. The savings generated internally by a company in the form of retained earnings are ploughed back into the company for diversification of its business. Retention of earnings by companies reduces their dependence on funds from external sources in order to finance their regular business needs.

Retained earnings is favourable for companies as issuing of new capital is inconvenient as well as involve floatation costs also if company raises debt, the financial obligation and risk will increase. Retained earnings not only give rise to growth in the value of the firm but also appreciate the value of its shares. 


\section{Literature Review}

The review of studies which studied the subject matter of retained earnings is presented under this heading.

Rao (1977) analysed the financing practices of corporate sector from 1972 - 1975 using RBI statistics. His analysis showed that corporate gross saving was diverted to investment in fixed assets and a part of internal savings was used to finance inventory holdings.

Divatia and Shanker (1979) examined the capital formation and it's financing by the public and private limited companies. The result of their study revealed that internal sources played a dominant role in financing of capital formation for the period in between 1962 to 1976.

Rao and Vivekananda (1980) covered the period from 1950-51 to 1962-63, 1960-61 to 1970-71 and 1970-71 to 1974-75 to study the determinant of corporate savings. Their study was based on the aggregate manufacturing sector data of Reserve Bank of India. They concluded that the most important determinant of corporate savings was corporate income. In addition, they found that savings were positively related to investment demand and liquidity position.

Myers and Majluf (1984) concluded that investment decisions made by managers were subject to the pecking order of financing choices available. Managers preferred retained earnings to debt and debt to equity floatation to finance the available projects.

Mayer (1990) in his study found that two third on the average of investment financing in developed countries like USA, UK, Japan, Germany, France, Italy, Canada and Finland are mobilized through internal financing.

Donaldson (1961) in his study viewed and established the importance of retained earnings as the funds over which management has complete and independent control.

Mittal (1992) examined the determinants of retained earnings covering a period of ten years (1980 -1990) and the sample size consisted of 23 large textile public companies of the public sector. The study concluded that retained earnings decision was a residual one this was because of the variation in dividends payments which was very low in comparison to the variations in retained earnings in large sized textile companies. Current ratio had the most significant effect on retention ratio whereas debt equity ratio and corporate tax rate had a depressing effect on retention ratio. The desire to hold more inventories and to avoid interest burden not significantly induced the managements to retain more profits.

Karak (1993) concluded that management in India, as a rule has recently followed conservative policies with regard to dividends. There was an increasing tendency on their part to finance the expansion out of internal resources as far as possible.

Athey and Laumas (1994) examined the importance of accelerator, internal funds and depreciation for investment by manufacturing firms in India covering a period from 1978 to 1986. Results of the study indicated that internal funds and depreciation had a significant 
explanatory power in a sales accelerator model of investment and that there existed heterogeneity among firms in the link between internal funds and investment. In particular internal funds were relatively more important for large firms and firms that produced luxury goods.

Bartram (2000) found that the availability of internal funds or retained earnings guarantee the realization of profitable investment projects and at the same time avoid higher capital cost.

Kumar (2001) examined the financing pattern in India for the period from 1956 to 1999 using RBI statistics, results of his study showed that internal funds were the major source of funds in the 1950s.

Salvary (2004) attempted to determine whether allocation of regional financial capital flow was efficient as suggested by the neo classical model, specifically the study attempted to ascertain whether the corporate retained earnings model was a good predictor of the regional flow of financial capital. The results of the study suggested that the corporate retained earnings model had an impact on the predictive ability of the neo classical model, that is regional flows of financial capital were influenced in part by corporate retained earnings.

Saggar S (2005) analyzed the financing and investment pattern of non-financial, nongovernment, public limited firms over the period 1971-72 to 1999-2000 of majority industry groups. On the source side, the financing pattern of Indian firms was found to be debt based but their share of internal sources increased markedly in the latter half of the 1990s which had an impact on share prices.

RBI (Reserve Bank of India, 2005) study observed that the corporate sector in India has mobilised a large share of resources from internal sources which accounted for $60.7 \%$ during 2000-01 to 2004-05.

Mahakud (2005) analyzed the trends and the determinants of retained earnings. For trends in the retained earnings, the study was conducted on public limited companies, private limited companies and foreign companies in India during the period 1966-67 to 2001-02. The determinants of corporate retained earnings were studied using panel data pertaining to 500 companies listed in S\&P CNX 500 index for the period1996-97 to 2003-04. Results of the study found that the corporate retained earnings in India were not increased much and remained at a low level throughout the period of study. As regards the determinants of retained earnings it was concluded that profit after tax, investment opportunities, availability of external funds, cost of borrowings, dividend policy and the shareholding patterns had been the major determinants of retained earnings.

Kaushik (2007) examined the factors that acted as determinants of retained earnings with a comparative study of domestic and multinational companies. Sample size consisted of 100 companies (50 domestic and $50 \mathrm{MNCs}$ ); the study covered a period of 15 years i.e. from 1990 to 2004. The study concluded that there existed a significant difference between domestic and multinational companies with regard to the manner in which retained earnings were managed and also the factors that determined retained earnings. 
Salvary (2007) studied the problem of under investment, risk management and corporate earnings retention for a period from 1983 to 1990 consisting of 45 firms for purpose of study. Study concluded that risk management was viewed as the management of firm's operations activities and financing practices to produce a portfolio of risks which resulted in average pay off. The two most common forms of risk mitigation i.e. insurance and hedging does not addressed the under investment problem, corporate earnings retention by means of dividend policy provided a firm with an important means of risk mitigation.

Kamat (2008) investigated the trends in dividends across 20 industries to know how the private corporate sector of India appropriated its profits over period from 1961 to 2007. He also examined whether internal funds were a significant source of finance and the dynamics of relation between dividends relative to earnings across type of companies and industries. Results of the study showed that Indian corporate sector paid relatively more dividends, the paying of cash dividends decreased with shareholder concentration and regulated companies paid relatively larger dividends, dividend payouts for all type of companies declined after liberalization period thus, indicating a greater choice of internal financing by means of retained earnings.

Seppa (2008) showed that Estonian non-financial companies followed pecking order theory of financial hierarchy while making capital structure choices as they preferred internal funds to external funds. The results provided no or very weak supports that the tradeoff theory was followed in the long run.

Beena P L (2011) analysed the sources of financing pattern Indian private corporate sector for the period from 1999 to 2009. Result of the study found an increasing trend in internal finance since year 2000 and retained earnings contributed a major share of finance during the period of study.

As far as review of earlier studies on determinants of retained earnings, it is seen that a very few studies attempted to identify the determinants of retained earnings in India.

\section{Research Methodology}

This part explains the scope, objectives, period of study, sample size, database, statistical tool, and development and testing of hypotheses.

\section{Scope}

The paper aims to identify the determinants of retained earnings in profitable steel companies of steel sector in India for a time period of sixteen years i.e. 1995-96 - 2010-11.

\section{Objectives}

The paper aims is to meet the following objectives:

1) To identify the determinants of retained earnings in profitable steel companies of steel sector in India.

2) To study the importance of retained earnings as a source of finance for steel companies. 


\section{Source of Data}

The paper is based on the secondary data collected from the CMIE (Center for Monitoring of Indian Economy) Prowess Database.

\section{Sample Selection and Period of Study}

The sample size consists of 27 profitable steel companies. The period of study ranges from 199596 to $2010-11$, i.e. a period of 16 years.

The technique of selecting the sample of number of companies for selected steel sector companies is judgmental sampling. The number of sample companies in is given below as obtained from the CMIE Prowess database.

\section{List of Sample Companies in Selected Sector}

\begin{tabular}{|l|l|l|}
\hline Sr. No. & Sector & No. of Companies \\
\hline $1-$ & Steel & 27 \\
\hline Total & 27 \\
\hline
\end{tabular}

The number of sample companies selected for steel sector is based on the following criteria. The necessary financial data required for study is available throughout the period of study i.e. from 1995-96 to 2010-11.

1) The number of sample companies selected for steel sector are profitable during the period of study.

2) The companies are listed on BSE (Bombay Stock Exchange).

3) The data required for study is available with the CMIE Prowess database (Centre for Monitoring of Indian Economy).

\section{Technique of Data Analysis}

The data collected relating to the sample steel companies for steel sector is analyzed using the statistical technique of multiple linear regression using SPSS version 19 (Statistical Package of Social Sciences). The technique of multiple linear regression has been applied primarily to minimize the problem of multi collinearity. This technique of multivariate analysis is used because it is the most appropriate tool for evaluating the individual and combined effect of a set of independent variables on dependent variable.

The significance of the coefficient of various explanatory variables is tested at $99 \%$ and $95 \%$ level of significance by computing beta $(\beta)$ and $t$ values.

\subsection{Variables of the Study}

A large number of variables, such as profit after tax, reserves, investments, depreciation etc.; affects or impacts the retained earnings of companies or retention of their earnings. All the possible variables that are believed to impact retained earnings have been incorporated in the model. 
- Retained Earnings (RE): Retained Earnings (RE) has been considered as the dependent variable and assuming a linear relationship, the following variables have been identified as independent variables. To be specific, the following have been considered as independent variable for the present paper.

- Profit after Tax (PAT): Profit after Tax is the net profit earned by the companies after deducting all expenses like interest, depreciation, taxes. It is the PAT that is divided between dividend and retained earnings.

- Dividend Paid (DP): Dividend is the portion of the profit after tax which is distributed to the shareholders .Dividend payment though increases the market price of share of companies but payment of dividends reduces the amount of after tax profits from which the companies can retain earnings.

- Reserves (RES): Creation of reserves enables companies to overcome difficult financial periods in future as such, they retain from profits to have adequate level of reserves to meet different financial obligations. Reserves of the organization also have an effect on the retention policy.

- Current Ratio (CR): Current ratio is the ratio of current assets to current liabilities, this ratio denotes how much liquid or liquidity companies have to meet their financial obligations within short period of time usually one year.

- Debt Equity Ratio (DER): Debt Equity Ratio is worked out to ascertain the soundness of the long term financial policies of the companies. Debt is considered to be a cheap source of finance as tax liability goes down with the payment of interest. In order to take full advantage of tax shield, the equity base needs to be strengthened by retaining the profits.

- Investment (INVS): Investments by companies also affect the retained earnings decision of companies and companies with high increase in investment in fixed assets in the current year are likely to retain more.

- Inventory (INV): Inventory consists of raw materials, finished goods, etc. To maintain sufficient level of inventories company's needs funds as such retained earnings of companies is internal and cheap source of funds which can be used in maintaining an adequate level of inventories for companies.

- Depreciation (DEP): Depreciation being a charge on profit that does not result in the outflow of cash is also likely to affect the retention behavior of companies. The higher the amount of depreciation, the lower is likely to be the retained earnings.

- Cash Flows (CF): Cash Flows refers to the inflows and outflows of cash by companies by way of receipts and payments

- Corporate Tax (CT): Corporate Tax is the tax which is paid by companies. Corporate Tax being a charge on profit and loss account, it is considered that the more outflow on account of it will result in less retained earnings.

Thus, the general model that has been considered for determination of relative role of each independent variable is:

$\mathrm{RE}=\mathrm{PAT}+\mathrm{DP}+\mathrm{RF}+\mathrm{CR}+\mathrm{DER}+\mathrm{INVS}+\mathrm{INV}+\mathrm{DEP}+\mathrm{CF}+\mathrm{CT}$

This model has been run using multiple linear regression in SPSS Version 19 (Statistical Package for Social Sciences). 


\subsection{Formation and Testing of Hypotheses}

As the objective is to identify the determinants of retained earnings for selected steel sector companies as such, a total of ten (10) hypotheses have been framed and tested.

In order to identify the determinants of retained earnings, the hypotheses have been framed on the basis of impact of independent variables on dependent variable i.e. retained earnings. The second objective of the paper which aims at studying the importance of retained earnings as source of finance for steel sector companies has been answered on the basis of review of literature of earlier previous studies carried out.

The hypotheses developed for steel sector companies are as follows.

H0 1(S): There is no significant impact of profit after tax (PAT) on retained earnings (RE) of steel sector companies.

H0 2(S): There is no significant impact of dividend paid (DP) on retained earnings (RE) of steel sector companies.

H0 3(S): There is no significant impact of reserves (RES) on retained earnings of steel sector companies.

H0 4(S): There is no significant impact of current ratio (CR) on retained earnings (RE) of steel sector companies.

H0 5(S): There is no significant impact of debt equity ratio (DER) on retained earnings (RE) of steel sector companies.

H0 6(S): There is no significant impact of investment (INVS) on retained earnings (RE) of steel sector companies.

H0 7(S): There is no significant impact of inventory (INV) on retained earnings (RE) of steel sector companies.

H0 8(S): There is no significant impact of depreciation (DEP) on retained earnings (RE) of steel sector companies.

H0 9(S): There is no significant impact of cash flows (CF) on retained earnings (RE) of steel sector companies.

H0 10(S): There is no significant impact of corporate tax (CT) on retained earnings (RE) of steel sector companies.

\section{Profile of Steel Industry}

The steel industry of India is a significant contributor to the Indian economy. The economic growth of Indian economy depends upon the growth of the steel industry. Demand by sectors like infrastructure, real estate etc. has put the Indian steel industry on the world map. The government of India opened up the steel industry to private investment as a result players entered into the industry thereby contributing to the economy.

The Indian steel industry enjoys the advantages of domestic availability of raw material and cheap labour. Steel industry of India has shown strong performance in recent past in terms of production, capacity utilization, exports and consumption. The Indian steel industry is divided into public and private sector. 


\section{Highlights of Steel Industry in India}

Steel industry in India contributes two percent of India's gross domestic product (GDP) and its weight age in index of industrial production (IIP) is 6.2\%.India is fourth largest producer of steel in the world after China, Japan and USA. Intended steel capacity build up in India is likely to result in investment of Rs 5 to 10 lakhs crore in 2020.The steel industry has made a rapid progress on strong fundamentals over the recent years getting all essential ingredients required for dynamic growth. The government is backing the industry through favorable industrial reforms while the private sector is supporting the steel industry by investments worth billion dollars.

\section{Analysis and Interpretation}

On the basis of analysis of data following interpretations have been made for framed hypotheses. Multiple regression results for steel sector companies have been given in analysis Table $\mathbf{1}$.

- For Null Hypothesis: H0 1(S), it has been found that there is a positive impact of PAT on $\mathrm{RE}$ and statistically the impact is highly significant as the significant value is less than $0.01(99 \%)$ and less than $0.05(95 \%)$ level of significance therefore, its alternate hypothesis is accepted.

- For Null Hypothesis: H0 2(S), it has been found that there is a negative impact of DP on $\mathrm{RE}$ and statistically the impact is highly significant as the significant value is less than $0.01(99 \%)$ and less than $0.05(95 \%)$ level of significance therefore, its alternate hypothesis is accepted.

- For Null Hypothesis: H0 3(S), it has been found that there is a neutral impact of RES on $\mathrm{RE}$ and statistically the impact is not significant as the significant value is greater than $0.01(99 \%)$ and greater than $0.05(95 \%)$ level of significance therefore, null hypothesis failed to be rejected.

- For Null Hypothesis: H0 4(S), it has been found that there is a positive impact of CR on $\mathrm{RE}$ and statistically the impact is significant as the significant value is less than 0.01 (99\%) and less than $0.05(95 \%)$ level of significance therefore, the null hypothesis is rejected and its alternate accepted.

- For Null Hypothesis: H0 5(S), it has been found that there is a neutral impact of DER on $\mathrm{RE}$ and statistically the impact is not significant as the significant value is greater than $0.01(99 \%)$ and greater than $0.05(95 \%)$ level of significance therefore, null hypothesis failed to be rejected.

- For Null Hypothesis: H0 6(S), it has been found that there is a neutral impact of INVS on $\mathrm{RE}$ and statistically the impact is not significant as the significant value is greater than $0.01(99 \%)$ and greater than $0.05(95 \%)$ level of significance therefore, null hypothesis failed to be rejected.

- For Null Hypothesis: H0 7(S), it has been found that there is a neutral impact of INV on $\mathrm{RE}$ and statistically the impact is significant as the significant value is greater than 0.05 (95\%) but less than 0.01 (99\%) level of significance therefore, its alternate hypothesis is accepted.

- For Null Hypothesis: H0 8(S), it has been found that there is a negative impact of DEP on $\mathrm{RE}$ and statistically the impact is significant as the significant value is greater than 0.05 
$(95 \%)$ but less than $0.01(99 \%)$ level of significance therefore, its alternate hypothesis is accepted.

- For Null Hypothesis: H0 9(S), it has been found that there is a neutral impact of CF on $\mathrm{RE}$ and statistically the impact is not significant as the significant value is greater than $0.01(99 \%)$ and greater than $0.05(95 \%)$ level of significance therefore, null hypothesis failed to be rejected.

- For Null Hypothesis: H0 10(S), it has been found that there is a negative impact of CT on $\mathrm{RE}$ and statistically the impact is not significant as the significant value is greater than $0.01(99 \%)$ and greater than $0.05(95 \%)$ level of significance therefore, null hypothesis failed to be rejected.

The value of R Square (coefficient of determination) in Table $\mathbf{1}$ for steel sector is equal to 0.82 which indicates that $82 \%$ variance in the dependent variable i.e. retained earnings is explained by the independent variables.

Analysis Table 1 of Steel Sector

\begin{tabular}{|c|l|l|l|l|}
\hline Variable & Beta $(\boldsymbol{\beta})$ & $\mathbf{t}$ & Sig. & R Square \\
\hline Constant & & -23.084 & 0.000 & 0.82 \\
\hline PAT & 1.025 & 2342.228 & $0.000^{* *}$ & \\
\hline DP & -0.950 & -773.143 & $0.000^{* *}$ & \\
\hline RES & 0.000 & 0.106 & 0.916 & \\
\hline CR & 0.946 & 1020.645 & $0.000 * *$ & \\
\hline DER & 0.000 & -0.264 & 0.792 & \\
\hline INVS & 0.000 & 0.136 & 0.892 & \\
\hline INVN & 0.002 & 2.214 & $0.027 *$ & \\
\hline DEP & -0.001 & -2.261 & $0.024 *$ & \\
\hline CF & 0.000 & -0.073 & 0.942 & \\
\hline CT & -0.745 & 0.453 & 0.651 & \\
\hline
\end{tabular}

** Represents Significant at $99 \%$ level of significance

* Represents Significant at $95 \%$ level of significance

\section{Conclusion}

On the basis of analysis in the present paper it is concluded that following variables have been found to be the important determinants of retained earnings of steel companies of steel sector in India under study with their impact on retained earnings.

PAT showed positive impact on the retained earnings and is statistically significant. DP showed negative impact on the retained earnings and is statistically significant. RES showed a neutral impact on retained earnings and is statistically not significant. CR has a positive impact of on retained earnings and is statistically significant. DER has a neutral impact on retained earnings and is statistically not significant. INVS showed a neutral impact on retained earnings and is statistically not significant. Impact of INV on retained earnings is neutral and is statistically 
significant Impact of DEP on retained earnings is negative and is statistically significant. The impact of variable $\mathbf{C F}$ on retained earnings is neutral and is statistically not significant.

The impact of variable CT on retained earnings is negative and is statistically not significant.

The present paper also concludes that importance of retained earnings as a source of finance for steel companies is immense and of significant importance. The importance of retained earnings is established by the fact that retained earnings is an internally generated source of finance by companies from their after tax profits. The management of companies has complete and independent control regarding the decision to retain earnings after paying reasonable dividends to their shareholders. The conclusion for this objective are supported by the studies of Beena (2011), Bhayani ( 2009), Salvary (2007), Sagar S (2005), RBI ( 2005), Bartram (2000).

\section{References}

[1] Athey, J. M. and Laumas, S. P. (1994), Internal Funds and Corporate Investment in India, Journal of Development Economics, 45, 287-303, http://www.jstor.org.com, accessed on 4th February 2009.

[2] Bhayani, S. J. (2009), Dividend Payout Policy: An Empirical Analysis of Indian

[3] Bartram, S. M. (2000), Corporate Risk Management as a Lever for Shareholder Value Creation, Financial Markets, Institutions and Instruments, 9(5), 279- 324.

[4] Beena, P. L. (2011), Financing Pattern of Indian Corporate Sector under Liberalisation: With Focus on Acquiring Firms Abroad, Working Paper 440, Centre for Development Studies, Trivananthpuram, Kerala (India), 1- 47.

[5] Divatia, V.V. and K. S. (1979), Capital Formation and Its Financing in the Private Corporate Sector, Journal of Income and Wealth, 3(2), 118-152,http://www.elsevier.com, accessed on 16th July 2009.

[6] Donaldson, G. (1961), Corporate Debt Policy, Harvard University Press, Boston, U. S. A.

[7] Kaushik, K.P. (2007), Determinants of Retained Earnings in Highly Profitable Companies of India: A Comparative Study of Domestic \& Multinational Companies, The ICFAI Journal of Applied Finance, 13(6), 19-42.

[8] Kamat, S. M. (2008), The Ownership and Industry Effects of Corporate Dividend Policy In India, 1961-2007, MPRA Paper No 12545, 1-20.

[9] Karak, H. (1993), Dividend Profit and Dividend Decision, The Management Accountant, 235237.

[10] Mahakud, J. (2005), Corporate Retained Earnings in India: Trends and Determinants, The ICFAI Journal of Applied Finance, 11, 59-72.

[11] Mittal, R.K. (1992), Determinants of Corporate Retained Earnings, Indian Management, 31, 35 38.

[12] Mayer, A. and Colin R. (1990), Financial Systems, Corporate Finance and Economic Development, NBER, Chicago University Press, U.S.A.

[13] Myer, S. C. and Majluf, N. S. (1984), Corporate Financing and Investment Decisions When Firms Have Information that Investors do not Have, Journal of Financial Economics, 13, 187 221, http://www.elsevier.com, accessed on 17th January 2009.

[14] Rao, Subba K.G.K. (1977), Shift In The Pattern of Financing of Capital Formation In The Private Corporate Sector, RBI Staff Occasional Papers, 2(1), 136-148.

[15] Rao, V.G. and Vivekananda, M.A. (1980), The Determinants of Corporate Saving Behaviour, Margin, 12, 38-50.

[16] Reserve Bank of India (RBI). (2005), RBI Report on Currency and Finance, Mumbai, India. 
[17] Salvary, C.W.S. (2007), The Underinvestment Problem \& Corporate Earnings Retention, The ICFAI Journal of Financial Risk Management, 1 4(2), 7-24.

[18] Seppa, R. (2008), Capital Structure Decisions: Research in Estonian Financial Companies, Baltic Journal of Management, 3(1) 55-70, http://www.emerald.com, accessed on 24th December 2010.

[19] Saggar, S. (2005), Financing and Investment Pattern of Indian Firms, Economic and Political Weekly, January 15, 2005.

[20] Salvary, C. W. S. (2004), The Neo Classical Model, Corporate Retained Earnings and The Regional Flows of Financial Capital, Canisus College, U.S.A, 1-46.

Annexure: Name of Steel Companies selected in Steel Sector.

(1)Electro Steel Castings Ltd. (2) Inox India Ltd. (3) Jai Corp Ltd. (4) Jindal Saw Ltd.

(5) L G Balakrihnan\& Bros Ltd. (6) Laksmi Precision Screws Ltd. (7) M M Forgings Ltd.

(8)Maharashtra Seamless Ltd. (9) Monnet Ispat \& Energy Ltd. (10) Man Industries Ltd. (11) P S L Ltd. (12) Rajratan Global Wire Ltd. (13) Ratnamani Metals \& Tubes Ltd. (14) Sathavana Ispat Ltd. (15) Shivalik Bimetals \& Control Ltd. (16) Sterling Tools Ltd. (17) Surana Industries Ltd.(18) Taparia Tools Ltd. (19) Tata Sponge Iron Ltd. (20) Tata Steel Ltd. (21) Tube Investment of India Ltd. (22) Tulsyan N E C Ltd. (23) Mahindra Forgings Ltd. (24) J S W Steel Ltd. (25)Advance Steel Tubes Ltd. (26) Bhushan Steel Ltd. (27) Sterlite Industries( India) Ltd.

\footnotetext{
*Corresponding author.

E-mail address: sohaib28@ gmail.com
} 